\title{
Gas Price Policy Analysis for Fertilizer Industries in Indonesia Based on Netback from Final Product
}

\author{
Erwan Hermawan ${ }^{1}$, Widodo Wahyu Purwanto ${ }^{2}$ \\ ${ }^{1,2}$ Department of Chemical Engineering, Faculty of Engineering, Universitas Indonesia, Depok 16424, \\ Indonesia. \\ 1erwan.hermawan@ui.ac.id \\ 2widodo@che.ui.ac.id
}

Received: 03/09/2020.

Reviewed: $18 / 11 / 2020$.

Published: 31/12/2020.

Copyright $\odot 2020$ by the author (et al) and Jurnal Sosial Humaniora (JSH)

*This work is licensed under the Creative Commons Attribution International License (CC BY 4.0).

http://creativecommons.org/licenses/by/4.0/ Open Access

\begin{abstract}
Subject Area: Economic
Abstract

The industrial sector has an important role in the Indonesian economy. The problem facing the fertilizer industry is the price of gas as a raw material that tends to be expensive for the lower prices of crude oil since 2016. To overcome this problem the government issued Presidential Regulation No. 40/2016 on setting gas prices for the fertilizer industry but this regulation only sets floor gas prices at USD 6/MMBTU to secure revenues of gas producers. Meanwhile, the current sale gas contract for fertilizer applies an escalation. The objectives of this study are to evaluate the netback value of each fertilizer plant and assess the current gas price policy. The netback value is calculated based on the long-run marginal cost of urea production. The result shows that PKT 04 and PKT 05, Pusri 1B, 2B, 3, and 4, PKC $1 A$ and $1 B$, and PKG have lower netback value than gas price contract, except for PKT plant based on average has the highest netback value, because they use pricing mechanism that linked to oil and product price. From this calculation the current gas price policy needs to be adjusted to keep the fertilizer industry profitably.
\end{abstract}

Keywords: Gas price policy; netback value; fertilizer

\section{Introduction}

The industrial sector has an important role for the Indonesian economy. In 2017 Indonesian GDP for the manufacturing and non-processing industries contributed around 38.2\% from Indonesia's total GDP around Rp. 995 trillion. The fertilizer, petrochemical, and oleo chemical industries contributed around Rp. 248 trillion (Airlangga, 2016). The problem facing the industry today is that domestic gas prices tend to be expensive. The impact of this situation is high cost of production especially the industry using natural gas as feedstock. Share of feedstock for fertilizer and petrochemical production costs is around $70 \%$. The high gas price is because the gas gas price contract uses is a fixed price mechanism with escalation, so gas prices tend to increase even though oil prices are down.

To overcome natural gas prices problem, the government issued Presidential Regulation No. 40/2016 concerning gas pricing. In this regulation gas prices are regulated for seven main industries, including fertilizer industry. The derivative regulation is Minister of Energy and Mineral Resources Regulation No. $16 / 2016$ concerning gas pricing for certain industries, which is the floor price for gas contract at USD 
6/MMBTU. The determination of gas price based on the availability of natural gas for the user and the impact of economic growth from the added value provided by the industry.

In 2015 the Minister of Trade sent a letter (No. 524/M-IND/11/2015) to the Minister of Energy and Mineral Resources (ESDM), The fertilizer industries stated that if the gas price is still above USD 5/MMBTU, they ask the government to set the maximum gas price of USD 5/MMBTU without escalation. Based on the cost structure, for cost of fertilizer processing, the Indonesian fertilizer plant is quite efficient. However, cost of raw materials is not competitive with some other countries. From an industrial standpoint, lower gas prices will reduce production costs, and make output cheaper (Nugroho, et al, 2018). Based on pricing theory, that pricing mechanism should create a price balance between consumers and producers (Tooth, 2014). In previous research, to determine electricity tariffs in Oman used the long run marginal cost (LRMC) method (Malik, 2006). It uses the difference between the market price of product and the long run marginal cost is than resulting netback value (Mian, 2011). Therefore, through this study a netback value calculation is performed to obtain the willingness to pay of gas for fertilizer industry and the policy recommendations is suggested.

\section{Methodology}

In the netback value calculation, the first step is estimating the investment costs for the fertilizer plant, fixed costs, and variable costs. Fixed costs and variable costs are obtained by benchmarking some of the literature (Pupuk Indonesia, 2017; World Bank,1998). The plant cash flow is prepared from the first plant operating until 2019. The netback value obtained is then compared with the gas price contract.

\section{Fixed Cost Calculation}

Table 1 shows PT. Pupuk Indonesia plant profile which estimates the investment cost.

\begin{tabular}{|c|c|c|c|}
\hline \multirow[t]{2}{*}{ Pabrik } & \multirow{2}{*}{$\begin{array}{l}\text { Tahun } \\
\text { berdiri }\end{array}$} & \multicolumn{2}{|c|}{$\begin{array}{c}\text { Kapasitas ( ribu } \\
\text { ton) }\end{array}$} \\
\hline & & Urea & Ammonia \\
\hline PKT 2 & 1982 & 570 & 590 \\
\hline PKT 3 & 1986 & 570 & 330 \\
\hline PKT 4 & 2002 & 570 & 330 \\
\hline PKT 5 & 2015 & 1.155 & 825 \\
\hline PKT 1A & 1999 & 570 & 660 \\
\hline PKC 1A & 1978 & 570 & 330 \\
\hline PKC 1B & 2003 & 570 & 330 \\
\hline Pusri IB & 1994 & 570 & 446 \\
\hline Pusri III & 1976 & 570 & 330 \\
\hline Pusri IV & 1977 & 570 & 330 \\
\hline Pusri IIB & 2016 & 908 & 660 \\
\hline PKG & 2016 & 570 & 825 \\
\hline \multicolumn{4}{|l|}{ Note: } \\
\hline \\
\hline & \\
\hline & \multirow{2}{*}{\multicolumn{2}{|c|}{ : PT. Pupuk Kujang Cikampek }} & \\
\hline \multicolumn{3}{|c|}{ Pusri : PT. Pupuk Sriwidjaja Palembang } & \\
\hline
\end{tabular}


Plant investment costs is estimated by using Six-ten rule equation and the CEPCI Index. Fixed costs are calculated by several constituent costs such as fixed operations and maintenance (O\&M), depreciation, insurance costs, administrative and general overhead, and loans. The ratio between debt and equity is 65:35 (Appl M, 1999; World Bank, 1998).

\section{Variable Cost Calculation}

Variable costs are the main processing cost of ammonia and urea. This includes feedstock, electricity, processes, catalysts, molecular sieves, inert materials, solvents, lube, and seal oil, and water. The urea variable costs are ammonia, $\mathrm{CO} 2$, fuel gas for crystallization, prilling, and compression, stripping ammonia and CO2, electricity, CO2 separation, and water make up (IEAGHG. 2017; Kermeli, et al, 2017; Baboo, 2018).

\section{Netback Calculation}

Cash flow is calculated since the plant first started operating until 2019. The internal rate of return (IRR) is set at $8 \%$. Ammonia prices use is FOB Southeast Asia (SE), while the urea price is FOB Indonesia. Netback value is obtained from cash flow, the netback is calculated based on the results of the long run marginal cost calculation of urea production (equation 1).

Figure 1. Marginal cost calculation

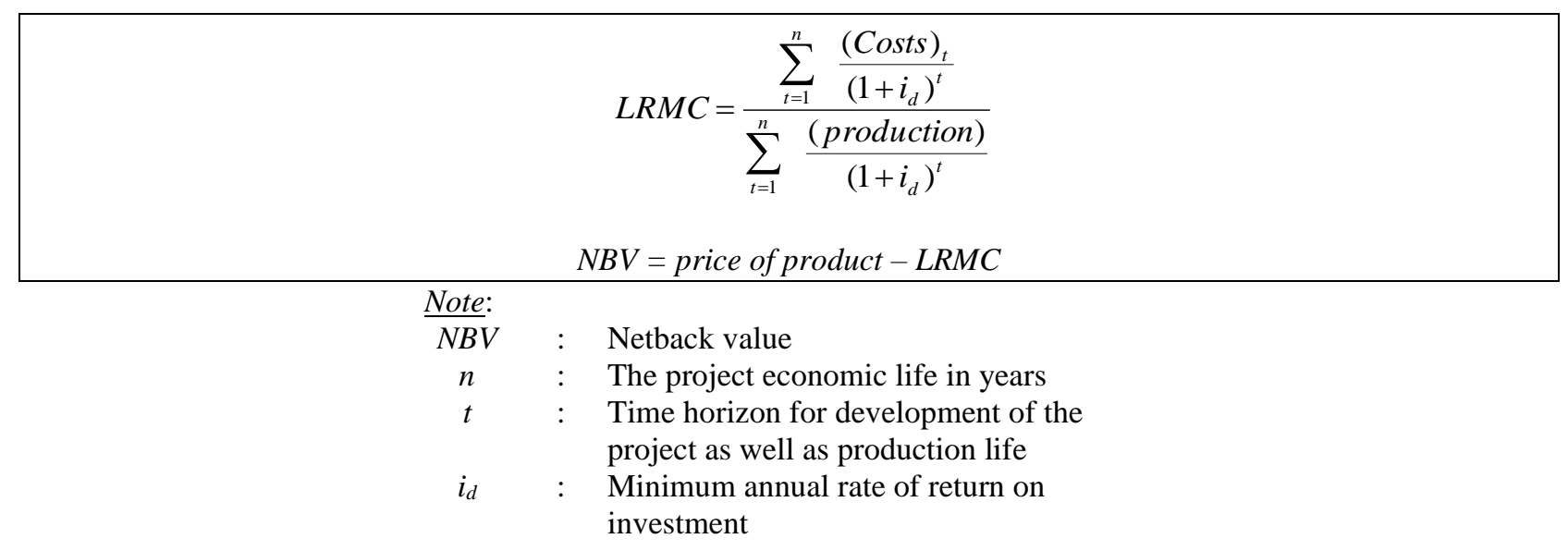

Note that the NBV is calculated without cost of feedstock and the LRMC calculated annually (capital expenditure, operating expenditure, and production).

\section{Result and Discussion}

\section{Urea Production Costs}

Figures 2 is the results of non-gas costs ammonia and urea calculation. In this case, Ammonia production is used to be feedstock for urea production, while the remaining ammonia production is by product which is an additional netback value. The historical data ammonia and urea non-gas cost curves 
are not always flat. Non-gas costs of each plant are influenced by the cash flow conditions of each plant. For example, for the PKC's in 2017 there was a decrease value in non-gas cost, because the PKC 1B's in that year had finished making capital investment financing payments. While the increase in costs is due to the new plant investment so that there is an increase in costs, such as in 2015 there was an increase in nongas costs in the PKT's, this is because in that year the PKT's spent money to build the PKT 5 plant. in 2016, Pusri also experienced an increase due to new investment to build the Pusri 2B plant. PKG's is the highest non gas cost, because PKG's just only has one plant which was buil in 2016 and PKG's must return the investment costs for the next 15 years (Fortez, et al, 2014; Fertecon, 2019).

Figure 2. Non gas cost urea production

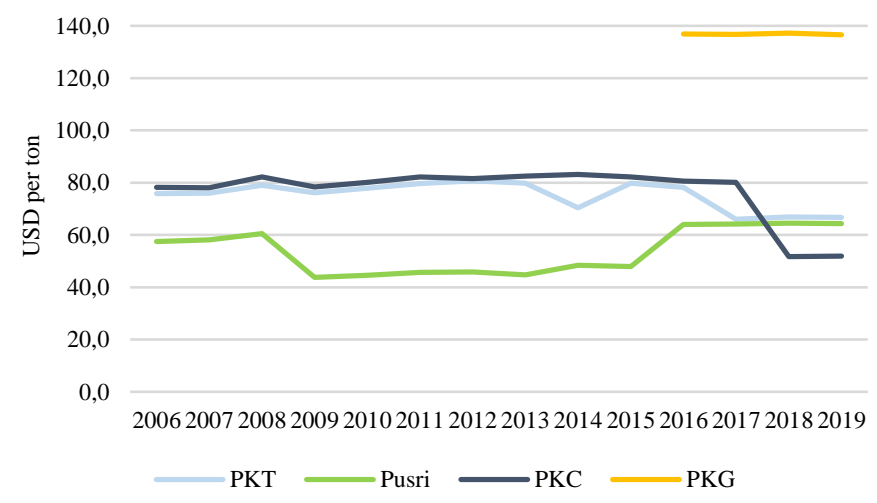

In Figures 3, the gas costs more volatile. In general, the gas price contract uses fixed price mechanism plus escalation, except PKT's. PKT's gas cost tend to be more volatile because the contract gas price formula used by PKT's with the contractor refers to the crude oil, ammonia and urea price. It can be seen in 2008 the PKT's gas cost increased sharply, because in that year the oil price was increased significantly.

Figure 3. Non gas cost urea production

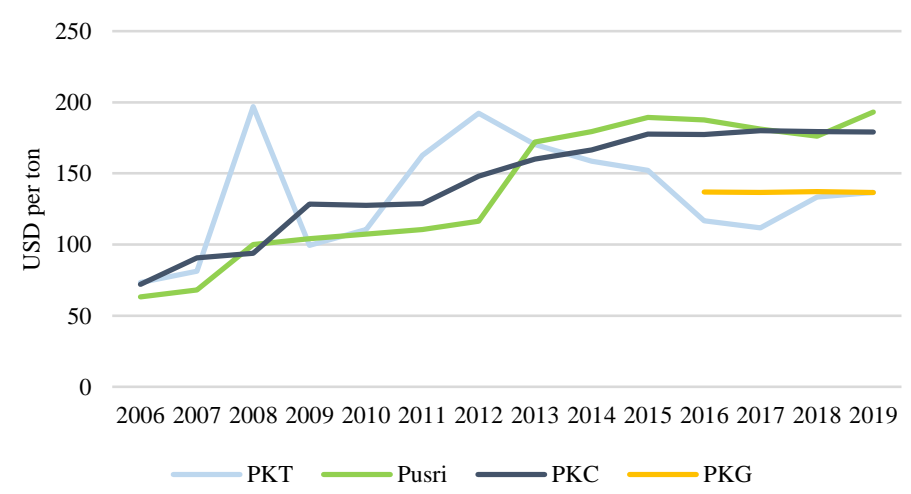

The production costs of urea have continued to increase from 2006 to 2019, it can be seen at Figure 4. The Growth of production costs for urea is $+4 \%$ per year (CAGR). Gas cost is the main cost element with share $60 \%-71 \%$. On the other hand, gas prices at that time were still much cheaper compared to 2019 gas prices. During the oil crisis in 2008 the gas cost component increased by $64 \%$ compared to 2006 only 
$50 \%$, and the trend of gas costs continued to rise to reach $71 \%$ in 2015 from the total fertilizer production costs.

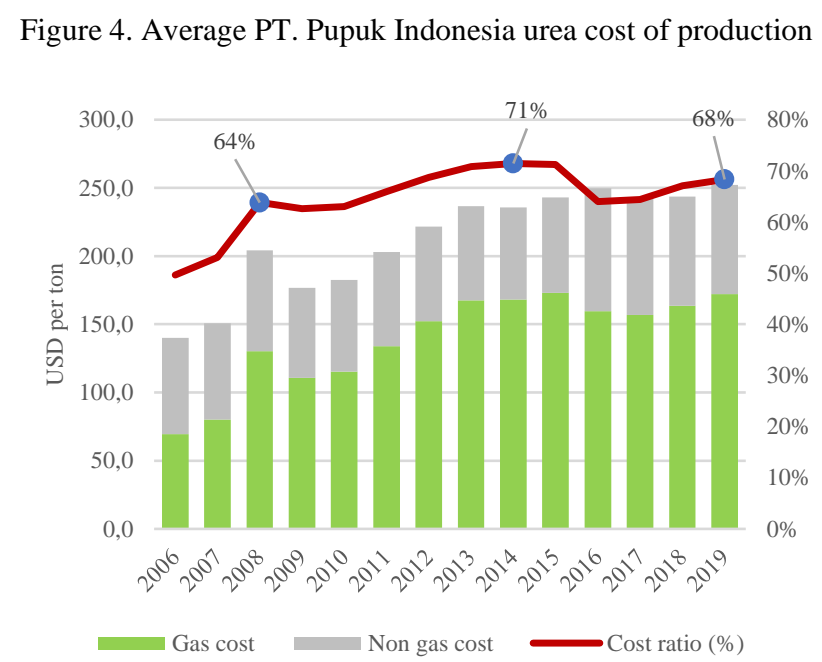

\section{Comparison of Production Costs}

The cost comparison of urea production and gas prices in some countries is describes in Figure 4, the cost of urea production by PT. Pupuk Indonesia is highest among fertilizer producing countries. PT. Pupuk Indonesia's gas price is still much higher compared to other countries. When viewed from the regulatory aspect, each region has a different pricing mechanism, for the Middle East the gas price can reach USD 1.4 per MMBTU with a total production cost of only USD 119 per ton of urea because in the Middle East region tends to use a different pricing mechanism regulated based on political and social aspects. Nearly $76 \%$ of Middle Eastern countries adopt a gas pricing system that is regulated. The government provides subsidies of USD 0.5 per MMBTU to USD 3 per MMBTU. Subsidies are given to provide a more beneficial economic impact on other sectors.

Gas prices in Venezualla are set by the government below cost. This causes the price of gas in the country to be the lowest among fertilizer producing countries. Like the countries of Algeria and Africa which set gas prices below cost, so the gas price is only USD 1.55 per MMBTU and USD 1 per MMBTU. Unlike in Ukraine, this country has the same gas pricing mechanism as Indonesia, which is based on social and political conditions. We see that the average gas price in Ukraine is USD 5.6 per MMBTU, higher than USD 0.21 per MMBTU as figure 5 shows. Now the government still needs non-tax government revenue from the oil and gas sector. 
Figure 5. Comparison of the cost of urea production and gas prices

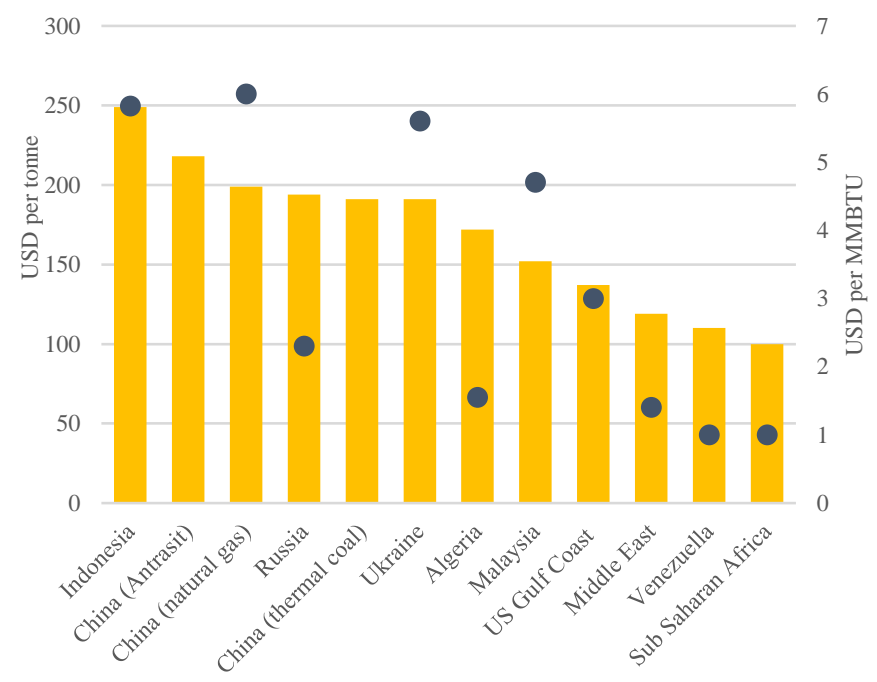

In the Asian region, Indonesia is still unable to compete for urea products. Compared to Malaysia, the price of Indonesian urea fertilizer is still not competitive. The cost of urea fertilizer production in Malaysia is only USD 152 per ton of urea. China uses several types of raw materials for urea production, such as gas and coal. China is the largest country in the world for gas consumption, where $30 \%$ of total world gas consumption comes from China. Gas prices in China vary from USD 5.7-6.6 per MMBTU supplied from unconventional gas production or imports from pipelines or LNG (Kirova, 2017; Nieuwenhuyse, 2000). The high price of gas raw materials in China does not impact to the cost of urea production in China to become more expensive than Indonesia, which is only USD 199 per ton of urea. While the cost of urea production from raw materials from coal can still compete with Indonesian urea products. This is because China has large urea capacity and production (throughput). This is a potential competitor of Indonesian Fertilizer because the cost of fertilizer production in the two countries is more competitive compared to the cost of Indonesian urea production. Based on gas consumption, PT. Pupuk Indonesia has highest gas consumption with average gas consumption up to 29 MMBTU per ton urea. In contrast to the Middle East countries, besides the low gas price, the gas consumption for urea production is lower than Indonesia with average consumption 22-27 MMBTU per ton urea. Compared to Malaysia, Petronas Fertilizer Company consumption 24 MMBTU per ton urea (Yara, 2018; Bazzanella \& Ausfelder, 2017). Malaysian fertilizer plant much more efficient than Indonesia.

\section{Netback Analysis}

There are several plants that have a netback value below the gas price contract in 2019, such as:

Table 2. Comparison of netback and contract price in 2019

\begin{tabular}{ccc}
\hline Plant & Netback Price & Contract Price \\
& $($ USD/MMBTU) & (USD/MMBTU) \\
\hline
\end{tabular}




\begin{tabular}{lcc}
\hline PKT 4 & 4.40 & 5.02 \\
PKT 5 & 4.30 & \\
\hline Pusri 1B & 4.39 & \\
Pusri 2B & 4.69 & 6.0 \\
Pusri 3 & 4.67 & \\
Pusri 4 & 4.62 & 5.83 \\
\hline PKC 1A & 4.54 & 7.0 \\
PKC 1B & 4.41 & \\
\hline PKG & 4.95 & \\
\hline
\end{tabular}

In Table 2 almost fertilizer plants have a netback value below the gas price contract due to gas cost always escalating each year. This situation happened because the gas contract formula is dominated by escalation scheme which used by Pusri's. PKC's, and PKG's. The PKT's using linked to oil formula, only two plants which have low netback value that are PKT's 4 and 5.

Figure 6-9 show the relationship between the calculated netback value and the contract gas. The average netback value of each plant has decreased since 2012. Almost company which using escalation contract mechanism have netback value lower than gas price contract. PKC's from 2015 to 2019 the netback value was below the contract gas price which continued to escalate. PKG's is a new plant, the netback value was higher than the contract price in 2018 with netback value USD 7.07 per MMBTU, but in 2019 the netback value fell to USD 4.95 per MMBTU, while the price of gas increased to USD 7.09 per MMBTU.

From the four plants, only the PKT's has not experienced netback value intersect with the contract gas price. Pusri's netback value has intersected with contract gas prices since 2015, From this calculation shows that each company has different willingness to pay, generally PKT's has the best netback value. Whereas other plant since the last four years showed a decrease in netback value.

Except gas price, gas consumption also effecting netback value. Some plants which were built in or around 1970 has high gas consumption, such as Pusri's 3, Pusri's 4, and PKC's 1A with gas consumption per ton urea reached until $35 \mathrm{MMBTU}$ per ton urea. Except gas price as a driver for total cost of production, the plant efficiency also could affect the cost of production.

Figure 6. Comparison of Pusri netback and gas contract

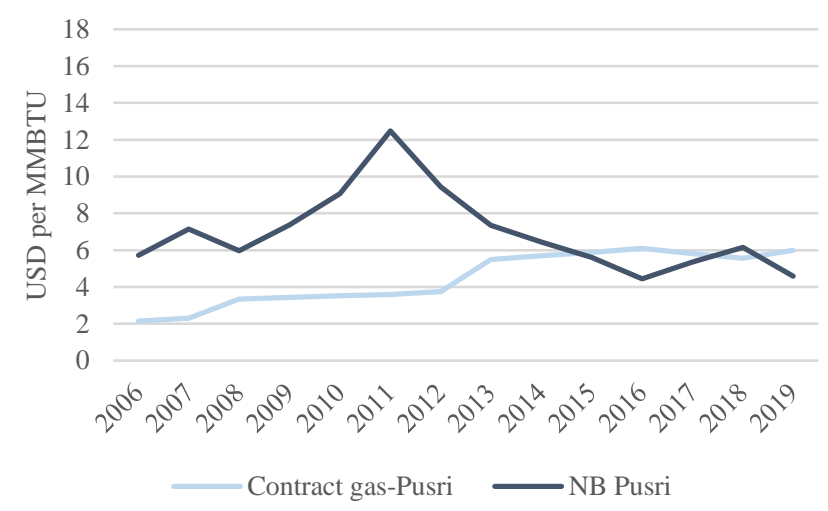


Figure 7. Comparison of PKC netback and gas contract

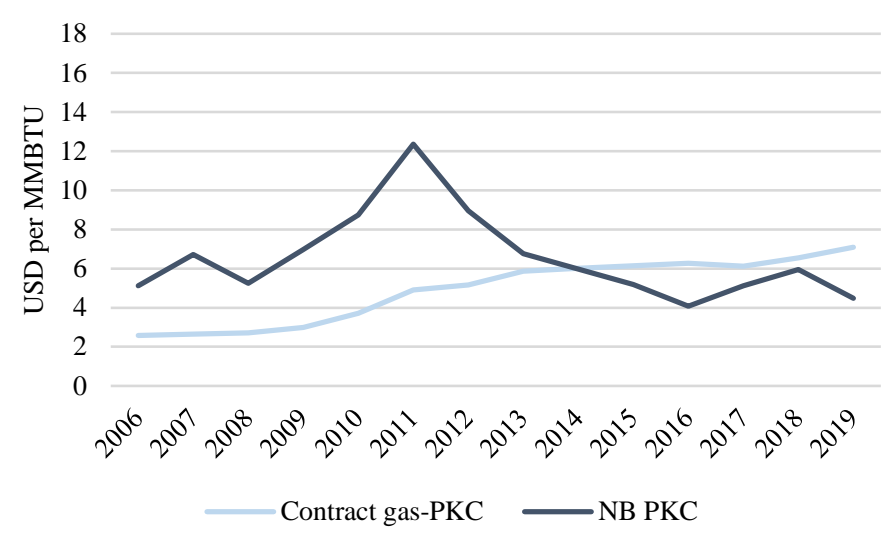

Figure 8. Comparison of PKC netback and gas contract

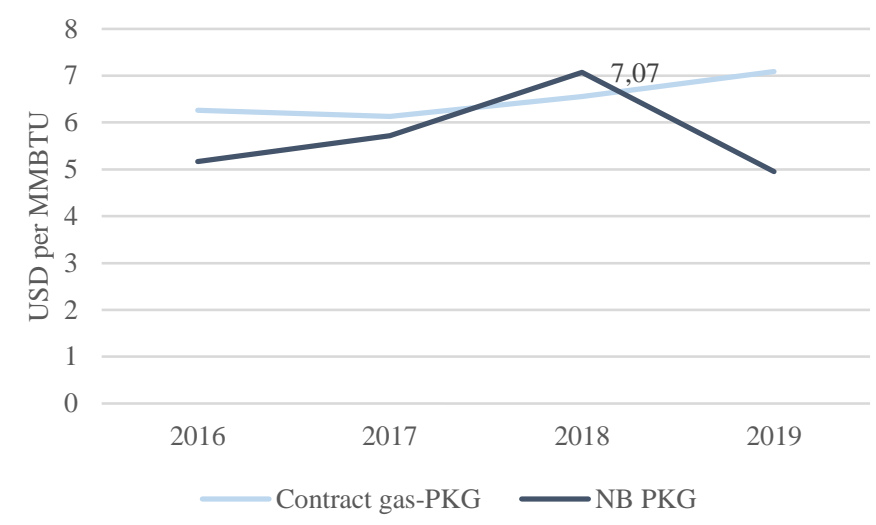

Figure 9. Comparison of PKT netback and gas contract

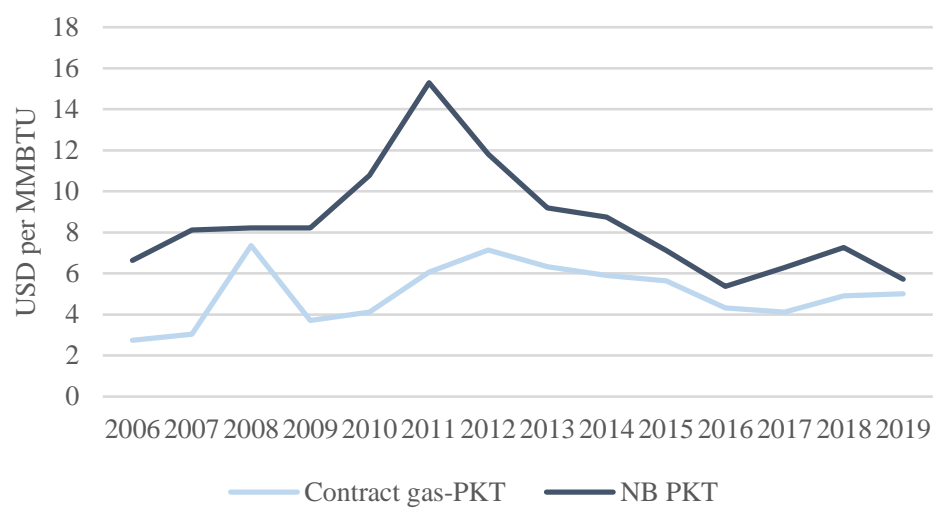

When compared all average netback value among fertilizer plants (Figure 9), the PKT's has the highest average netback value. This is because when viewed based on gas costs (Figures 4), PKT's have the lowest gas cost among all plants. PKT's uses indexed to crude oil and product prices as a formula (Figure 10), so that in the period of low oil prices (2016-2019) PKT's gas costs also fall because gas prices 
were driven by crude oil prices. In contrast to other plant that have lower netbacks because they use a contract mechanism for escalating gas prices, causing gas costs to continue to rise (Figure 11).

Figure 10. Average netback calculation

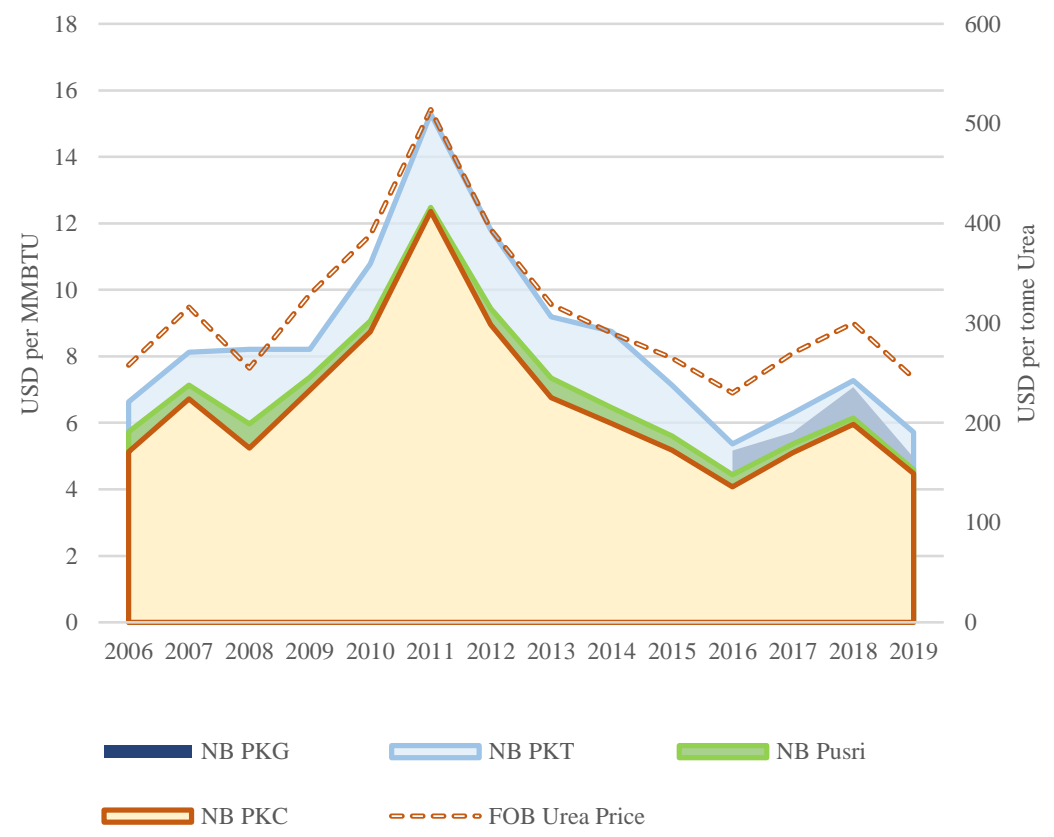

The relationship between product price and netback value (Figure 11), the netback value is highly dependent on the price of urea. When the price of a product is high, the willingness to pay for gas as a feedstock will also be high, so that the fertilizer plant will get the maximum profit when the product price is high. But on the contrary if the price of the product is low, starting from 2011 to 2019 shows a downward trend in fertilizer prices, then that is when the fertilizer companies will experience a decline in profits from the sales of fertilizer products. The prices of market products continue to fall, since 2006 the price of urea has shown a declining trend in prices (CAGR $-0.4 \%$ ). Based on this situation, the government intervention is needed to protect product prices so that the company can survive facing the declining trend in fertilizer product prices. This has been discussed in the previous section that oil prices also have a downward trend after 2011. 
Figure 11. Comparison of escalation price formula (PKC, Pusri, and PKG) and ICP

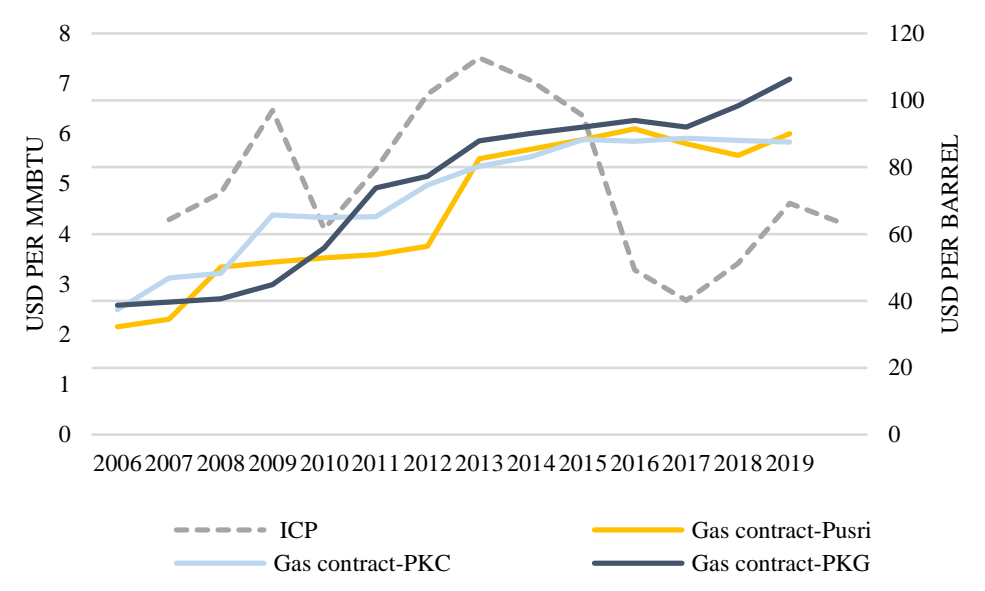

Figure 12. Comparison of escalation price formula (PKC, Pusri, and PKG) and ICP

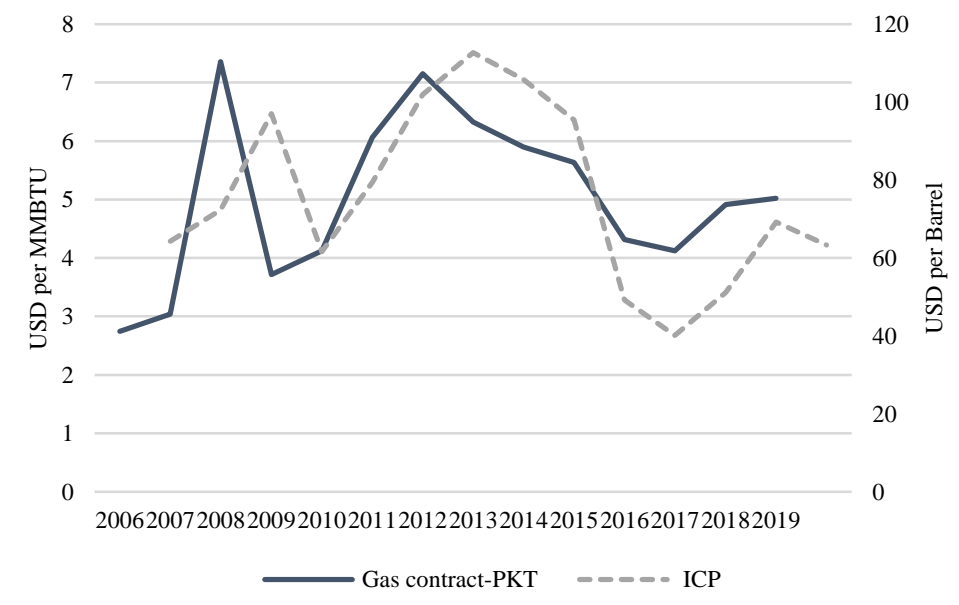

\section{Policy Analysis}

There are several formulations for determining gas prices, one of which is linked to product prices and crude oil prices. Almost of Pupuk Indonesia's gas contracts with oil and gas contractors implement an escalation pricing system, so gas prices are not sensitive with the changes in crude oil prices or product prices. In general gas contracts use an escalation mechanism, only the PKT's uses a price mechanism indexed by product prices and crude oil prices. Basically, based on Figure 11 and 12, the average Pupuk Indonesia's gas price is growth (CAGR) 7\% per year. The contract gas price that reflects the price of crude oil price is PKT's. Whereas other Indonesian Pupuk subsidiaries show gas price trends that tend to rise (Wang \& Zhu, 2018).

The average gas price of Pupuk Indonesia's netback value (Figure 13) from 2006 to 2011 increased dramatically with a growth of $5.6 \%$ per year. At that time, the average gas contract price for Indonesian Fertilizers was vulnerable at 2.4 - 4.5 USD per MMBTU. In that period, it was a period where fertilizer factories gained a large profit. There is a gap in the price of gas netbacks with the price of gas contracts 
which is quite high. Between 2012 to 2019 crude oil prices continue to fall and the value of the netback has also decreased until in 2016 there began to be an intersection between the price of the gas contract with the netback price. Overall, from 2006 to 2019 the netback value of fertilizer factories experienced negative growth of $-1.3 \%$ per year. Escalation gas contracts will not be sensitive to changes in oil prices, so that in the period 2016 to 2019 fertilizer plants will suffer a period of low product prices and have an impact on weakening netback value.

Figure 13. Average netback value PT. Pupuk Indonesia

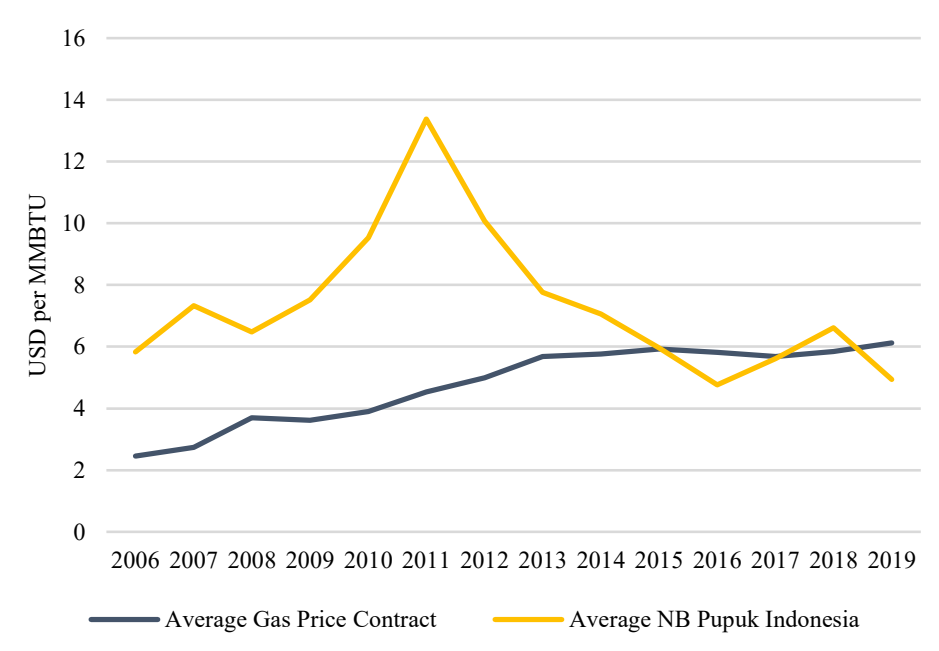

Based on the results of this study the following are gas price policy recommendations:

- It would be better if the gas price were determined using an automatic fuel adjustment mechanism, because it would be able to provide gas prices based on market conditions (such as PKT plant-Figure $11)$.

- The government needs to provide additional incentives for the fertilizer industry to revitalize old factories so that it can reduce plant production costs by reducing gas consumption, because based on the calculation of production costs (Figure 6-7), the production costs of the Indonesian Fertilizer plant are still unable to compete with production costs in some fertilizer producing countries, especially China and Malaysia.

- From the user side, the government needs to set floor price limits refer to Permen ESDM 16/2016 not only based on consideration of the potential reduction in non-tax government revenue from oil and gas sector, but most importantly from netback calculation (Figure 11).

\section{Conclusion}

Based on the netback calculation results, in 2019 the average netback of PT. Pupuk Indonesian is below the contract price of USD 5 per MMBTU, while the average gas contract price has reached USD 6.12 per MMBTU. Historically, the contract gas prices tend to escalate, this is an unbalanced condition. The price of gas should ideally follow the price of crude oil such as PKT's gas price formula. It can apply 
a formula mechanism based on automatic fuel adjustment. From the production side, the cost of fertilizer production in Indonesia is also still unable to compete with fertilizer producing countries such as China and Malaysia, subsidies and incentives from the government are needed to reduce production costs and ensure fertilizer prices in the market can compete with imported products. Current policy shows that the gas price contract basically escalates from year to year, the price control of the gas price reduction limit (USD 6 per MMBTU) is not only based on the aspect of non-tax government revenue, but also needs to pay attention to the aspect of netback pricing which is calculated based on the marginal cost of fertilizer production.

\section{References}

Appl M. (I999). Ammonia: Principles and Industrial Practice. Toronto: Wiley-VCH.

Baboo, P. (2018). Urea Plant Energy Improved with Operation Philosophy \& Reactor Internal. International Journal of Engineering Research \& Technology (IJERT) Vol. 7, 70-79.

Bazzanella, A. M. \& Ausfelder, F. (2017). Low carbon energy and feedstock for the European chemical industry. Frankfurt: DECHEMA.

Fertecon. (2019). Urea Outlook 2019.

Fortez, M. P., Dumitriu, \& Tzimas. (2014). CO2 Utilization Pathways: Techno-Economic Assessment and Market Opportunities. Energy Procedia 63, 7968-7975.

Hartarto, Airlangga (2016), Bahan Rapat Harga Gas Untuk Industri. Retrieved from coordination meeting. Jakarta, 15th August 2016.

IEAGHG. (2017). Techno Economic Evaluation of HYCO Plant Integrated to Ammonia/Urea or Methanol Production with CCS.

Kermeli, K., Worrel, Graus, \& Corsten. (2017). Energy Efficiency and Cost Saving Opportunities for Ammonia and Nitrogenous Fertilizer Production. United Stated Environmental Protection Agency.

Kirova, Zornitza. (2017). Exergy-based estimation and comparison of urea and ammonium nitrate production efficiency and environmental impact. Energy 140, 158-169.

Malik, Arif S. (2006). Electricity Tariffs Based on Long-Run Marginal Costs for Central Grid System of Oman. Energy volume 31, 1703-1714.

Mian, M. A. 2011. Project Economics and Decision Analysis. Oklahoma: Penwell.

Nieuwenhuyse, (2000). Production of Ammonia. Belgium: European Fertilizer Manufacture Association.

Nugroho, Ando \& Amir, Hidayat, (2018). Analisis Dampak Insentif Fiskal Penetapan Harga Gas Bagi Industri Domestik Terhadap Perekonomian: Pendekatan Model CGE Dinamis. Kajian Ekonomi dan Keuangan, Volume 2, pp. 40-51.

Pupuk Indonesia, (2017). Annual Report Pupuk Indonesia 2017, Jakarta: s.n

Tooth, R., (2014). Measuring Long Run Marginal Cost for Pricing, Sydney: Sapere Reasearch Group.

Wang, Y., \& Zhu, Z. (2018). Cost of Natural Gas in Eastern Chinese Markets: Implications for LNG Imports. IAEE Energy Forum, 21-28.

World Bank. 1998. Fertilizer Sector Restructuring Project. 
Yara. (2018). Yara Fertilizer Industry Handbook. 